\title{
Deoxyribonucleic Acid Hybridization Among Strains of Actinomyces viscosus and Actinomyces naeslundii
}

\author{
ALAN L. COYKENDALL AND ALLAN J. MUNZENMAIER \\ Department of Oral Diagnosis, School of Dental Medicine, University of Connecticut, \\ Farmington, Connecticut 06032
}

\begin{abstract}
Deoxyribonucleic acids (DNA) were extracted from strains of Actinomyces viscosus and Actinomyces naeslundii and were compared by DNA-DNA hybridization. When their DNAs were compared by hybridization on membrane filters, $A$. viscosus strains from humans were barely separable from $A$. naeslundii strains, but $A$. viscosus strains from hamsters were distinctly different. $A$. viscosus strains from veterinary infections were identical to human strains. With the use of the more sensitive $S_{1}$ nuclease hybridization method with DNA from a set of strains that had been used in a numerical taxonomy study, typical $A$. viscosus strains from humans could be distinguished from typical $A$. naeslundii strains. A group of atypical $A$. naeslundii strains could also be delineated. The results generally parallel the taxonomic divisions of these organisms based on serology or numerical taxonomy. A. viscosus strains from humans and $A$. naeslundii strains are similar but distinguishable, but $A$. viscosus strains from hamsters are clearly separable.
\end{abstract}

Howell (12) and Howell and Jordan (13) described a filamentous organism which had been found associated with periodontal disease in laboratory hamsters (16). It closely resembled $A c$ tinomyces naeslundii but was catalase positive and hydrolyzed starch. Since catalase-positive organisms were not included in the genus Actinomyces at that time, the "hamster organism" was placed in a new genus and species, Odontomyces viscosus gen. nov. (14).

When it was recommended that catalase-positive bacteria be accepted in the genus Actinomyces, Odontomyces viscosus was renamed Actinomyces viscosus (8). Gerencser and Slack (9) isolated $A$. viscosus strains from human mouths and found that they differed serologically from the hamster organism. Hamster strains were designated serotype 1 , and human strains were designated serotype 2. Georg et al. found both $A$. viscosus serotypes 1 and 2 in veterinary infections (7). Both hamster and human $A$. viscosus strains as well as $A$. naeslundii strains will cause periodontal disease in experimental animals $(15,16,21)$. However, there are distinct differences between $A$. viscosus and $A$. naeslundii. They can be distinguished by their catalase reaction, cell wall carbohydrates, and serological properties (20). However their overall phenotypic similarity is great, and when compared by numerical taxonomic methods the two species are similar $(6,11)$. To clarify the relationships among $A$. naeslundii, human $A$. viscosus, and animal $A$. viscosus strains, deoxyribonucleic acids (DNAs) from several strains of these or- ganisms were compared based on their ability to form hybrid duplexes.

\section{MATERIALS AND METHODS}

Bacterial strains. The hybridization experiments were carried out by two methods and on two groups of strains. The first study was a comparison of several strains by hybridization of their DNA on membrane filters (Table 1). Later, a number of strains which had been extensively characterized for a numerical taxonomy study (6) became available through the kindness of E. D. Fillery, University of Toronto, Toronto, Canada (Table 2). This second group was compared by DNA hybridization in free solution, using singlestrand-specific nuclease (1). This method was considered more precise (2) and was employed to increase the discrimination between $A$. naeslundii and $A$. viscosus serotype 2 because filter experiments indicated that although they were not identical, the "border" between $A$. viscosus and $A$. naeslundii was indistinct. Furthermore, we wished to discriminate, if possible, Fillery's cluster 3 strains which resemble $A$. naeslundii but are biochemically and serologically different from both cluster 1 ("typical" $A$. viscosus serotype 2) and cluster 5 ("typical" $A$. naeslundii). Thus the results of a numerical taxonomic study would be directly compared with those of a DNA hybridization study. Two additional strains, $\mathrm{T} 14 \mathrm{~V}$ and $\mathrm{T} 14 \mathrm{AV}$, were included. $\mathrm{T} 14 \mathrm{~V}$ is said to be periodontopathic in gnotobiotic animals, whereas the substrain T14AV is not (10). A colony from each strain was picked from a CNAC-20 agar plate (5), and pure cultures were obtained. The cultures were Gram stained and tested for the following: catalase activity; nitrate and nitrite reduction; starch and lactose fermentation; gelatin liquefaction; methyl red reaction; urease and indole production; esculin hydrolysis; and the Voges-Proskauer reaction. 
TABLE 1. Strains used in filter hybridization experiments

\begin{tabular}{|c|c|c|}
\hline Strain & Origin/reference & Donor $^{a}$ \\
\hline \multicolumn{3}{|l|}{$\begin{array}{l}\text { A. viscosus strains from animals } \\
\text { (serotype } 1 \text { ) }\end{array}$} \\
\hline$\underset{15987)^{b}}{\operatorname{WVU} 745}(=\mathrm{T} 6=\mathrm{ATCC}$ & Hamster mouth (12) & Gerencser \\
\hline WVU440 ( = X601 = HS2) & Hamster mouth (12) & Gerencser \\
\hline A1231 & Dog abdomen abscess (7) & Fillery \\
\hline $\mathrm{A} 1351^{\mathrm{c}}$ & Pig lung (7) & Fillery \\
\hline $\mathrm{A} 1353^{\mathrm{c}}$ & Goat lymph node (7) & Fillery \\
\hline $\mathrm{W} 1308^{c}$ & Dog liver abscess $(7)$ & Fillery \\
\hline \multicolumn{3}{|l|}{$\begin{array}{l}\text { A. viscosus strains from humans } \\
\text { (serotype } 2 \text { ) }\end{array}$} \\
\hline WVU 845 & Human dental plaque & Ellen \\
\hline P1 & Human dental plaque & Ellen \\
\hline P2 & Human dental plaque & Ellen \\
\hline $34 a_{1}$ & Human dental plaque & Ellen \\
\hline M100 & Human dental plaque (15) & Tanzer \\
\hline UCHC-BIB & Human dental plaque (22) & Tanzer \\
\hline UCHC-HAs & Human dental plaque (22) & Tanzer \\
\hline UCHC-R3A & Human dental plaque (22) & Tanzer \\
\hline UCHC-TO4 & Human dental plaque (22) & Tanzer \\
\hline \multicolumn{3}{|l|}{ A. naeslundii strains } \\
\hline $\mathrm{C} 2$ & Human dental plaque & Ellen \\
\hline N9 & Human dental plaque & Ellen \\
\hline $43 e_{1}$ & Human dental plaque & Ellen \\
\hline WVU820(= N16) & Human dental plaque (15) & Gerencser \\
\hline WVU45 $(=\text { ATCC 12104 })^{d}$ & Human sinus (9) & Gerencser \\
\hline WVU398A & Human dental calculus (9) & Gerencser \\
\hline WVU631 & Human dental calculus (9) & Gerencser \\
\hline
\end{tabular}

${ }^{a}$ M. A. Gerencser, West Virginia University, Morgantown; E. D. Fillery, University of Toronto, Toronto, Ontario, Canada; R. P. Ellen, University of Toronto; J. M. Tanzer, University of Connecticut, Farmington.

${ }^{b}$ Type strain of A. viscosus. ATCC, American Type Culture Collection, Rockville, Md.

${ }^{c}$ Serologically similar to $A$. viscosus serotype 2 (7).

${ }^{d}$ Reference strain; candidate for designation as type strain.

All strains conformed to the descriptions of $A$. viscosus and $A$. naeslundii as reported by Slack and Gerencser (20).

Isolation of DNA. Cells of these species are difficult to lyse, and upon lysis they seem to release a deoxyribonuclease (DNase) which rapidly decreases the viscosity of the suspension, and DNA cannot be recovered. The following method gave moderate lysis and milligram quantities of DNA. Cells were grown in 2 to 4 liters of Trypticase soy broth (BBL, Cockeysville, Md.) supplemented with $10 \mathrm{mmol}$ of $\mathrm{NaHCO}_{3}$ per liter. For radioactive DNA (index DNA), 1 or 2 $\mathrm{mCi}$ of $\left[\right.$ methyl. $\left.{ }^{3} \mathrm{H}\right]$ thymidine was added to the broth. Bacteria were cultured for 24 to $36 \mathrm{~h}$ in air plus $10 \%$ $\mathrm{CO}_{2}$ at $37^{\circ} \mathrm{C}$. Samples were taken to monitor growth turbidimetrically. Before growth stopped, $2.5 \mathrm{U}$ of penicillin per $\mathrm{ml}$ was added, and the cells were incubated for an additional 1 to $2 \mathrm{~h}$. The cells were then harvested, washed with water, suspended in $25 \mathrm{ml}$ of $0.15 \mathrm{M}$ tris(hydroxymethyl)aminomethane buffer $(\mathrm{pH}$ $8.0)$ containing $50 \mathrm{mg}$ of lysozyme $(2 \mathrm{mg} / \mathrm{ml})$ and incubated at $37^{\circ} \mathrm{C}$ for $2 \mathrm{~h}$. The cells were then removed from lysozyme and suspended in $25 \mathrm{ml}$ of $1 \times \mathrm{SSC}$ $(0.15 \mathrm{M} \mathrm{NaCl}+0.015 \mathrm{M} \mathrm{Na}$ citrate) and heated to $65^{\circ} \mathrm{C}$, at which time 1 to $2 \mathrm{ml}$ of $25 \%$ sodium lauryl sulfate was added. This treatment lysed the cells, and the suspension became quite viscous. When this viscosity reached a maximum, and before it started to decrease ( 2 to $4 \mathrm{~min}$ ), an equal amount of watersaturated phenol was added, and this mixture was shaken gently for $30 \mathrm{~min}$ at room temperature. The phenol appeared to halt most DNase activity. The DNA was purified by deproteinization with this phenol and then with chloroform; it was then treated with ribonuclease as described by Marmur (18). The final ethanol-precipitated product was dissolved and reprecipitated with isopropyl alcohol, which was added slowly to the DNA solution while it was blended in a Vortex mixer. DNA was stored frozen in $0.01 \times \mathrm{SSC}$ $(1.5 \mathrm{mM} \mathrm{NaCl}+0.15 \mathrm{mM}$ sodium citrate) for use in filter hybridizations and in $0.42 \mathrm{M} \mathrm{NaCl}$ for $S_{1}$ hybridization.

Determination of DNA base contents. The DNA base contents (as moles percent guanine plus cytosine [mol\% GC]) of the first group of strains were determined by thermal denaturation (19) in $0.25 \times \mathrm{SSC}$. With the use of Escherichia coli DNA as a standard it was found that, in $0.25 \times \mathrm{SSC}$, DNA denatured at $8.6^{\circ} \mathrm{C}$ below its normal denaturation point $\left(T_{m}\right)$ in normal-strength SSC. This correction factor was applied to all Actinomyces DNA thermal denaturation temperatures, and the mol\% GC was then calculated 
TABLE 2. Strains used in $S_{1}$ nuclease hybridization experiments

\begin{tabular}{|c|c|}
\hline Strain & Origin $^{a}$ \\
\hline \multicolumn{2}{|c|}{ Cluster 1 (typical $A$. viscosus strains) } \\
\hline WVU626 & Human mouth \\
\hline WVU627 & Human mouth \\
\hline AN6 & Human dental plaque \\
\hline Be66 & Human dentin \\
\hline H103 & Human dental plaque \\
\hline $\mathrm{W} 752^{h}$ & Wound abscess \\
\hline A1353 & Goat lymph node \\
\hline \multicolumn{2}{|c|}{ Cluster 3 (atypical $A$. naeslundii strains) } \\
\hline B120 & Human dental plaque \\
\hline B74 & Human dental plaque \\
\hline $\mathrm{H} 272$ & Human dental plaque \\
\hline \multicolumn{2}{|c|}{ Cluster 5 (typical $A$. naeslundii strains) } \\
\hline W 1096 & Human mouth \\
\hline W1048 $(=\text { ATCC 27039 })^{\prime}$ & Human infection \\
\hline 4A05 & Human dental plaque \\
\hline $\begin{array}{l}\text { X600 ( = WVU447, ATCC } \\
19039)\end{array}$ & Human dental plaque \\
\hline WVU398A & Human denial plaque \\
\hline WVU45 $(=\text { ATCC 12104) })^{d}$ & Human sinus \\
\hline \multicolumn{2}{|c|}{ Cluster 6 (atypical A. viscosus strains) } \\
\hline $\begin{array}{l}\text { W1053 ( = ATCC 27044 = } \\
\text { WVU474) }\end{array}$ & Human sputum \\
\hline \multicolumn{2}{|c|}{ Unclustered strains (A. viscosus strains) } \\
\hline $\mathrm{T} 14 \mathrm{~V}$ & Human mouth \\
\hline T14AV & $\begin{array}{l}\text { Avirulent form of } \\
\text { T14V }\end{array}$ \\
\hline
\end{tabular}

${ }^{a}$ All strains were from E. D. Fillery, except $A$. viscosus strains $\mathrm{T} 14 \mathrm{~V}$ and $\mathrm{T} 14 \mathrm{AV}$, which were from D. Birdsell, University of Florida, Gainesville.

${ }^{b}$ Catalase negative.

c ATCC, American Type Culture Collection, Rockville, Md.

${ }^{d}$ Candidate for designation as type strain.

by the formula mol\% GC $=\left(T_{m}-69.3\right) / 0.41$ (19). The high guanine plus cytosine content of the DNA of actinomyces necessitated the use of this dilute solvent.

Filter hybridizations. Quantities (50 $\mu \mathrm{g}$ each) of single-stranded DNA were applied to 25-mm Millipore type HAWP filters (Millipore Corp., Bedford, Mass.) and dried at $75^{\circ} \mathrm{C}$ for $4 \mathrm{~h}$. Filters were then immersed in vials containing $1.2 \mathrm{ml}$ of dimethyl sulfoxide (DMSO)-2 $\times \mathrm{SSC}(0.3 \mathrm{M} \mathrm{NaCl}$ plus $0.03 \mathrm{M}$ sodium citrate in $30 \% \mathrm{vol} / \mathrm{vol}$, aqueous DMSO [3, 17]). After $30 \mathrm{~min}$ at $62^{\circ} \mathrm{C}, 1.0$ or $0.5 \mu \mathrm{g}$ of single-stranded labeled index $\left[{ }^{3} \mathrm{H}\right]$ DNA was added to each vial, and the filters were incubated at $62^{\circ} \mathrm{C}$ for $18 \mathrm{~h}$. The filters were then rinsed extensively with DMSO-2 $\times \mathrm{SSC}$ at $62^{\circ} \mathrm{C}$ and dried, and the hybridized $\left[{ }^{3} \mathrm{H}\right] \mathrm{DNA}$ was quantitated by liquid scintillation. The extent of hybridization was determined by comparing the reassociation of index $\left[{ }^{3} \mathrm{H}\right] \mathrm{DNA}$ with unlabeled DNA of the same strain (the homologous control) to all other (heterologous) reassociations. $E$. coli DNA was used as a negative control. These experiments were done in duplicate.

$S_{1}$ hybridizations. When DNA was to be used for hybridization by the $S_{1}$ method, it was sheared by ultrasound for $1 \mathrm{~min}$ (four 15 -s periods with interven- ing ice water cooling) and dialyzed for at least $48 \mathrm{~h}$ against cold $0.42 \mathrm{M} \mathrm{NaCl}$. For hybridization, $25 \mu \mathrm{g}$ of DNA was mixed with $0.05 \mu \mathrm{g}$ of index $\left[{ }^{3} \mathrm{H}\right] \mathrm{DNA}$ in 1.25 $\mathrm{ml}$ of $0.42 \mathrm{M} \mathrm{NaCl}$ and denatured by heating to 115 to $120^{\circ} \mathrm{C}$ for $20 \mathrm{~min}$ in an ethyleneglycol-water bath. The mixture was allowed to reassociate at $70^{\circ} \mathrm{C}$ for 6 to 8 $\mathrm{h}$, after which unrenatured DNA was digested with 20 $\mathrm{U}$ of $\mathrm{S}_{1}$ nuclease for $20 \mathrm{~min}$ at $70^{\circ} \mathrm{C}$. The details of the $S_{1}$ method were described earlier (2). The method was adapted from Barth and Grinter (1). Remaining hybridized DNA was precipitated with $10 \%$ trichloroacetic acid, collected on glass-fiber filters (Whatman $\mathrm{GF} / \mathrm{C}$ ), and quantitated by liquid scintillation. Controls included a homologous reassociation as the positive control, $E$. coli DNA as a negative control, and controls of enzyme activity against double- and singlestranded DNA (2). For all $S_{1}$ experiments, the unlabeled DNAs were drawn from single batches isolated from each strain.

\section{RESULTS}

Hybridization on filters. Hybridizations on membrane filters showed that $A$. viscosus serotype-2 strain WVU845 $\left[{ }^{3} \mathrm{H}\right] \mathrm{DNA}$ hybridized extensively with the DNAs of some other serotype2 strains and somewhat less ( 70 to $80 \%$ ) with the DNAs of $A$. naeslundii strains and serotype-2 strains (experiment 1, Table 3 and Fig. 1). When A. naeslundii strain WVU398A $\left[{ }^{3} \mathrm{H}\right] \mathrm{DNA}$ was the index DNA (experiment 2), more separation between $A$. naeslundii and $A$. viscosus could be seen. DNAs from strains P1 and P2, which have characteristics of $A$. viscosus, did not hybridize well with index DNA. Taken together, experiments 1 and 2 indicate that $A$. viscosus and $A$. naeslundii are genetically somewhat different, but these experiments did not show two unequivocally distinct species. However, it is clear that the veterinary strains of $A$. viscosus (A1351, A1353, and A1231) were related to A. viscosus serotype 2 and that the hamster strains WVU745 and WVU440 are not closely related to either $A$. viscosus serotype 2 or $A$. naeslundii. The small experiment 3 confirmed that the two hamster strains were related to each other but not to any other strain from animal infections or humans. Experiment 4 showed that the three veterinary strains were related to each other and to $A$. viscosus serotype-2 strain WVU845 but not to strain W1308.

Hybridization using $S_{1}$ nuclease. The single-strand-specific nuclease $S_{1}$ digests DNA base sequences which are not accurately paired with complementary bases. Thus, nonspecific, specious duplexes are eliminated and the method emphasizes differences between microorganisms. The method successfully discriminated the three "clusters" detected by Fillery et al. (6).

Experiment 5 (Table 4, Fig. 2) showed that cluster 1 strains (A. viscosus) were homologous 
TABLE 3. Extent of DNA hybridization of Actinomyces strains as determined by the membrane filter method

\begin{tabular}{|c|c|c|c|c|}
\hline \multirow{2}{*}{ Source of unlabeled DNA } & \multicolumn{4}{|c|}{$\%$ of homologous reaction attained with the following reference strains: } \\
\hline & WVU $845^{a}$ & WVU $398 \mathrm{~A}^{b}$ & WVU745 & $\mathrm{A} 1353^{d}$ \\
\hline \multicolumn{5}{|l|}{$\begin{array}{l}\text { A. viscosus strains from hu- } \\
\text { mans (serotype } 2 \text { ) }\end{array}$} \\
\hline WVU845 & 100 & 73 & $-{ }^{e}$ & 93 \\
\hline $34 a_{1}$ & 106 & 59 & - & - \\
\hline M100 & 102 & 51 & 29 & - \\
\hline UCHC-BIB & 86 & 67 & - & - \\
\hline UCHC-HAs & 71 & 66 & - & - \\
\hline UCHC-R3A & 78 & 71 & - & - \\
\hline UCHC-TO4 & 107 & 86 & - & - \\
\hline P1 & 42 & 5 & - & - \\
\hline $\mathrm{P} 2$ & 36 & 2 & - & - \\
\hline \multicolumn{5}{|l|}{ A. naeslundii strains } \\
\hline WVU398A & 82 & 100 & - & - \\
\hline WVU631 & 35 & 98 & - & - \\
\hline $43 \mathbf{e}_{1}$ & 76 & 98 & - & - \\
\hline WVU820 & 85 & 79 & 46 & 50 \\
\hline WVU45 & 81 & 106 & - & - \\
\hline N9 & 78 & 85 & - & - \\
\hline $\mathrm{C} 2$ & 69 & 82 & - & - \\
\hline \multicolumn{5}{|l|}{$\begin{array}{l}\text { A. viscosus strains from ani- } \\
\text { mals (serotype 1) }\end{array}$} \\
\hline WVU745 & 53 & 54 & 100 & 68 \\
\hline WVU440 & 76 & 53 & 100 & 70 \\
\hline A1231 & 87 & 68 & 42 & 89 \\
\hline A1351 & 101 & 53 & 45 & 95 \\
\hline A1308 & - & - & - & 43 \\
\hline A 1353 & 87 & 73 & - & 100 \\
\hline E. coli & 15 & 2 & 4 & 8 \\
\hline
\end{tabular}

\footnotetext{
${ }^{a}$ Experiment 1 .
}

${ }^{b}$ Experiment 2.

' Experiment 3.

${ }^{d}$ Experiment 4 .

e-, Not done.

and were distinct from cluster 5 strains $(A$. naeslundii) and cluster 3 strains (atypical $A$. naeslundii). Similarly, experiment 6 showed that cluster 3 is distinct from clusters 1 and 5 . (We suspect that the high degree of hybridization with strain WVU626 in this experiment is an artifact.) Experiment 7 indicated that cluster 5 strains were not all homologous with the index strain WVU398A. However, the lack of relationship between clusters 1 and 5 and between 3 and 5 was confirmed. Another experiment (not shown) using $A$. naeslundii strain WVU45 $\left[{ }^{3} \mathrm{H}\right] \mathrm{DNA}$ as the index DNA produced similar results. DNA from strains of clusters 1 and 3 hybridized little with strain WVU45 $\left[{ }^{3} \mathrm{H}\right] \mathrm{DNA}$, but DNA from cluster 5 strains hybridized only moderately $(65$ to $70 \%)$ with the index $\left[{ }^{3} \mathrm{H}\right] \mathrm{DNA}$. Thus, although the $A$. naeslundii strains of cluster 5 may not be genetically homogeneous, they are certainly distinct from $A$. viscosus strains (cluster 1) and atypical " $A$. naeslundii" strains (cluster 3), as indicated by experiments 5 and 6 .

The DNAs from $A$. viscosus strains T14V and T14AV hybridized moderately with the DNAs of $A$. viscosus cluster 1 strains, indicating that they may not be typical of $A$. viscosus. However, small experiments using $\left[{ }^{3} \mathrm{H}\right] \mathrm{DNA}$ from T14V as the index DNA showed that $\mathrm{T} 14 \mathrm{~V}$ and $\mathrm{T} 14 \mathrm{AV}$ are indeed closely related to each other. In two experiments, T14AV DNA hybridized at 99 and $103 \%$ with T14V DNA.

DNA base contents. The DNA base contents of strains used in the filter hybridizations are listed in Table 5 . Nearly all strains had base contents between 66 and $68 \mathrm{~mol} \%$ GC. There was no significant difference in base content between $A$. viscosus and $A$. naeslundii. However, the somewhat higher guanine plus cytosine 


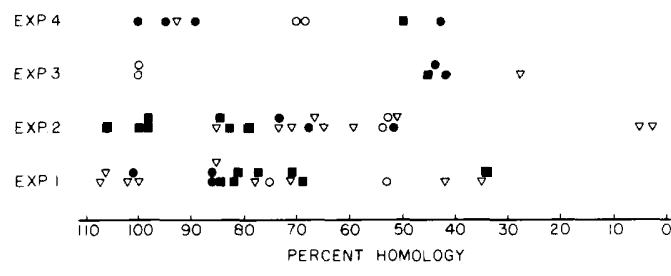

FIG. 1. Extent of DNA hybridization among various strains of $A$. viscosus and A. naeslundii. Hybrids were formed on membrane filters. Symbols: $\nabla, A$. viscosus strains from humans;,$A$. viscosus strains from animals; $O, A$. viscosus strains from hamsters; , A. naeslundii strains. The index strains were: experiment 1, WVU845; experiment 2, WVU398A; experiment 3, WVU745; experiment 4, A1353. They are always at $100 \%$ homology. content of the two hamster strains is notable in view of the lack of DNA homology between them and any other strains.

\section{DISCUSSION}

Currently the differentiation between $A$.naeslundii and $A$. viscosus is based on serological differences, the catalase reaction, and cell wall composition. The numerical taxonomy study of Fillery et al. (6) showed that typical $A$. viscosus serotype 2 strains could be separated from typical $A$. naeslundii strains when the overall results of 65 tests were compared (6), although their similarity was high $(88 \%)$ on a numerical scale. Thus, these two species are similar but

TABLE 4. Extent of DNA hybridization of Actinomyces strains as determined by the $S_{1}$ nuclease method

\begin{tabular}{|c|c|c|c|}
\hline \multirow{2}{*}{ Source of unlabeled DNA } & \multicolumn{3}{|c|}{$\begin{array}{l}\text { \% of homologous reaction attained with the following reference } \\
\text { strains: }\end{array}$} \\
\hline & WVU627 ${ }^{a}$ & $\mathrm{~B} 74^{b}$ & ${\text { WVU } 398 A^{c}}^{-}$ \\
\hline \multicolumn{4}{|l|}{$\begin{array}{l}\text { Cluster } 1 \text { (typical A. viscosus } \\
\text { strains) }\end{array}$} \\
\hline WVU627 & 100 & 38 & 35 \\
\hline AN6 & 90 & 53 & 32 \\
\hline W752 & 98 & 46 & 33 \\
\hline WVU626 & 85 & 78 & 30 \\
\hline A1353 & 87 & 53 & 35 \\
\hline Be66 & 87 & 48 & 38 \\
\hline H103 & 92 & 48 & 37 \\
\hline \multicolumn{4}{|l|}{$\begin{array}{l}\text { Cluster } 3 \text { (atypical } A . \text { naeslundii } \\
\text { strains) }\end{array}$} \\
\hline B74 & 56 & 100 & 45 \\
\hline $\mathrm{B} 120$ & 65 & 89 & 46 \\
\hline $\mathrm{H} 272$ & 66 & 82 & 50 \\
\hline \multicolumn{4}{|l|}{$\begin{array}{l}\text { Cluster } 5 \text { (typical } A . \text { naeslundii } \\
\text { strains) }\end{array}$} \\
\hline WVU398A & 46 & 21 & 100 \\
\hline WVU45 & 43 & 32 & 43 \\
\hline $4 \mathrm{~A} 05$ & 37 & 30 & 84 \\
\hline W1048 & 37 & 32 & 73 \\
\hline $\mathrm{X} 600$ & 42 & 38 & 61 \\
\hline W1096 & 28 & 27 & 52 \\
\hline \multicolumn{4}{|l|}{ Cluster 6} \\
\hline W 1053 & 70 & 30 & 36 \\
\hline \multicolumn{4}{|l|}{ Unclustered strains } \\
\hline $\mathrm{T} 14 \mathrm{~V}$ & 76 & 37 & 23 \\
\hline T14AV & 55 & 30 & 46 \\
\hline E. coli & 1 & 2 & $-^{d}$ \\
\hline
\end{tabular}

${ }^{a}$ Experiment 5 .

${ }^{b}$ Experiment 6 .

${ }^{c}$ Experiment 7.

${ }^{d}$-, Not done. 


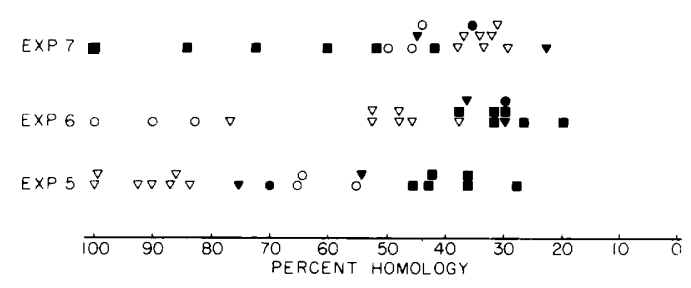

FIG. 2. Extent of DNA hybridization among $A$. viscosus and $A$. naeslundii strains which have been placed in clusters by numerical taxonomy. Hybrids were formed in solution. Cluster 1 strains are typical $A$. viscosus strains from humans $(\nabla)$; cluster 3 strains are atypical $A$. naeslundii strains $(O)$; cluster 5 strains are typical of $A$. naeslundii strains ( $\square$ ); cluster 6 strain is an atypical $A$. viscosus strain (O); and $T 14 V$ and $T 14 A V$ are $A$. viscosus strains $(\nabla)$. The index strains were: experiment 5, WVU627; experiment 6, B74; experiment 7, WVU398A. They are always at $100 \%$ homology.

TABLE 5. DNA base contents of some A. viscosus and $A$. naeslundii strains

\begin{tabular}{cc}
\hline Strain & $\begin{array}{c}\text { DNA base } \\
\text { content }^{*}\end{array}$ \\
\hline
\end{tabular}

A. viscosus (serotype 1 )

$\begin{array}{ll}\text { WVU745 } & 68.5 \pm 0.21 \\ \text { WVU440 } & 68.6 \pm 0.45 \\ \text { A1231 } & 67.9 \pm 0.58 \\ \text { A1351 } & 67.2 \pm 0.96 \\ \text { A1353 } & 67.5 \pm 0.98\end{array}$

A. viscosus (serotype 2)

$\begin{array}{ll}\text { WVU845 } & 66.5 \pm 0.51 \\ \text { P1 } & 67.8 \pm 1.24 \\ \text { P2 } & 67.4 \pm 0.21 \\ 34 a_{1} & 66.7 \pm 0.52 \\ \text { M100 } & 67.2 \pm 0.33 \\ \text { UCHC-BIB } & 68.0 \pm 0.29 \\ \text { UCHC-HAs } & 68.2 \pm 0.11 \\ \text { UCHC-R3A } & 67.2 \pm 0.10 \\ \text { UCHC-TO4 } & 67.5 \pm 0.29 \\ \text { T14AV } & 67.5 \pm 0.92 \\ \text { T14V } & 66.7 \pm 0.51\end{array}$

A. naeslundii

WVU398A $\quad 66.4 \pm 1.09$

WVU631 $\quad 68.1 \pm 0.69$

WVU820 $\quad 66.9 \pm 0.52$

WVU45 $\quad 67.4 \pm 0.47$

$\mathrm{C} 2 \quad 67.5 \pm 0.39$

$\mathrm{N} 9 \quad 68.1 \pm 1.11$

$\begin{array}{lll}43 \mathrm{e}_{1} & 67.5 \pm 0.61\end{array}$

E. coli

$50.5 \pm 0.91$

${ }^{a}$ Values indicate $\mathrm{mol} \% \mathrm{GC} \pm$ standard deviation.

not identical. The atypical strains of $A$. naeslundii (cluster 3) also formed a discrete cluster.

When strains of the two species were compared by DNA hybridization, the results were in general agreement with taxonomic divisions based on serological and numerical taxonomy methods. The filter method of hybridization was capable of separating $A$. viscosus serotype 1 (hamster strains) from $A$. viscosus serotype 2 (human strains) and also showed the similarity of serotype 2 and veterinary strains. On the other hand, $A$. naeslundii and $A$. viscosus serotype 2 were barely separable by the filter hybridization method. Use of the more discriminating $S_{1}$ hybridization technique revealed clear distinctions among typical $A$. viscosus strains from humans and typical $A$. naeslundii strains, as well as atypical $A$. naeslundii strains (Fillery's clusters 1,5 , and 3 , respectively). Thus, the phenotypic differences observed by Fillery et al. (6) and compared and contrasted by their computer methods, are manifestations of molecular differences whose underlying DNA base sequences are large enough to be detected by a lack of complete DNA hybridization, especially with the $S_{1}$ nuclease method.

The ability to separate these various groups on the basis of their genetic material as well as by traditional biochemical and serological methods has some taxonomic significance. We believe that $A$. viscosus serotype 2 and $A$. naeslundii should be separate species. In addition to their demonstrated serological, biochemical, and genetic differences, they have different ecologies (4), which may be imporant in the etiology of oral diseases. Their separation at species level seems logical and useful.

A. viscosus serotype 1 (hamster strains) appears to be quite different from $A$. viscosus serotype 2 . It may be necessary to regard hamster strains as a species separate from the organism of humans. Since the type strain of $A$. viscosus is a member of serotype 1 , the name $A$. viscosus must be reserved for serotype 1 . Thus, the serotype 2 strains would require a new species name if they were segregated from the serotype 1 (hamster) strains.

The strains of cluster 3 were also distinct from the other strains in this study, both by DNA hybridization and numerical taxonomy. They are catalase negative but share an agglutinable antigen with cluster 1 (A. viscosus) (6). They lack the precipitable antigens common to cluster 1 and 5 strains and have an $\alpha-6$-phosphogluconate dehydrogenase that is different from the enzyme of cluster 1 and 5 strains (6). These organisms also may deserve taxonomic recognition; they certainly deserve more study.

\section{ACKNOWLEDGMENTS}

This work was supported by Public Health Service grant DE-04721 from the National Institute of Dental Research. 
We thank Pauline Lizotte for determining many of the guanine plus cytosine contents of the DNAs, our colleagues for providing strains, and Carolann Manna for her preparation of the manuscript.

\section{REPRINT REQUESTS}

Address reprint requests to: Alan L. Coykendall, University of Connecticut, School of Dental Medicine, Department of Oral Diagnosis, Farmington, CT 06032.

\section{LITERATURE CITED}

1. Barth, P. T., and N. J. Grinter. 1975. Assay of deoxyribonucleic acid homology using a single-strand-specific nuclease at $75^{\circ} \mathrm{C}$. J. Bacteriol. 121:434-441.

2. Coykendall, A. L., and A. J. Munzenmaier. 1978. Deoxyribonucleic acid base sequence studies on glucanproducing and glucan-negative strains of Streptococcus mitior. Int. J. Syst. Bacteriol. 28:511-515.

3. De Ley, J., and R. Tijtgat. 1970. Evaluation of membrane filters for DNA-DNA hybridization. Antonie van Leeuwenhoek. J. Microbiol. Serol. 36:461-474.

4. Ellen, R. P. 1976. Establishment and distribution of $A c$ tinomyces viscosus and Actinomyces naeslundii in the human oral cavity. Infect. Immun. 14:1119-1124.

5. Ellen, R. P., and I. B. Balcerzak-Raczkowski. 1975. Differential medium for detecting dental plaque bacteria resembling Antinomyces viscosus and Actinomyces naeslundii. J. Clin. Microbiol. 2:305-310.

6. Fillery, E. D., G. H. Bowden, and J. M. Hardie. 1978. A comparison of strains of bacteria designated Actinomyces viscosus and Actinomyces naeslundii. Caries Res. 12:299-312.

7. Georg, L. K., J. M. Brown, H. J. Baker, and G. H. Cassell. 1972. Actinomyces viscosus as an agent of actinomycosis in the dog. Am. J. Vet. Res. 33:14571470.

8. Georg, L. K., L. Pine, and M. A. Gerencser. 1969. Actinomyces viscosus, comb. nov., a catalase positive, facultative member of the genus Actinomyces. Inst. J. Syst. Bacteriol. 19:291-293.

9. Gerencser, M. A., and J. M. Slack. 1969. Identification of human strains of Actinomyces viscosus. Appl. Microbiol. 18:80-87.

10. Hammond, B. F., C. F. Steel, and K. S. Peindl. 1976. Antigens and surface components associated with vir- ulence of Actinomyces viscosus. J. Dent. Res. 55:A19 A25 (Special Issue A).

11. Holmberg, K., and C. E. Nord. 1975. Numerical taxonomy and laboratory identification of Actinomyces and Arachnia and some related bacteria. J. Gen. Microbiol. 91:17-44.

12. Howell, A., Jr. 1963. A filamentous microorganism isolated from periodontal plaque in hamsters. I. Isolation, morphology and general cultural characteristics. Sabouraudia $3: 81-92$.

13. Howell, A., Jr., and H. V. Jordan. 1963. A filamentous microorganism isolated from periodontal plaque in hamsters. II. Physiological and biochemical characteristics. Sabouraudia 3:93-105.

14. Howell, A., Jr., H. V. Jordan, L. K. Georg, and L. Pine. 1965. Odontomyces viscosus, gen. nov., spec. nov., a filamentous microorganism isolated from periodontal plaque in hamsters. Sabouraudia 4:65-68.

15. Jordan, H. V., P. H. Keyes, and S. Bellack. 1972. Periodontal lesions in hamsters and gnotobiotic rats infected with Actinomyces of human origin. J. Periodontal Res. 7:21-28.

16. Keyes, P. H., and H. V. Jordan. 1964. Periodontal lesions in the Syrian hamster-III. Findings related to an infectious and transmissible component. Arch. Oral Biol. 9:377-400.

17. Legualt-Demare, J., B. Desseaux, T. Heyman, S. Seror, and G. P. Ress. 1967. Studies on hybrid molecules of nucleic acids I. DNA-DNA hybrids on nitro cellulose filters. Biochem. Biophys. Res. Commun. 28: $550-557$.

18. Marmur, J. 1961. A procedure for the isolation of deoxyribonucleic acid from microorganisms. J. Mol. Biol. 3: 208-218.

19. Marmur, J., and P. Doty. 1962. Determination of the base composition of deoxyribonucleic acid from its thermal denaturation temperature. J. Mol. Biol. 5:109-118.

20. Slack, J. M., and M. A. Gerencser. 1975. Actinomyces, filamentous bacteria. Biology and pathogenicity. Burgess Publishing Co., Minneapolis, Minnesota.

21. Socransky, S. S., C. Hubersak, and D. Propas. 1970 Induction of periodontal destruction in gnotobiotic rats by a human oral strain of Actinomyces naeslundii. Arch. Oral Biol. 15:993-995.

22. Tanzer, J. M., A. M. Slee, B. Kamay, and E. R. Scheer. 1977. In vitro evaluation of three iodine-containing compounds as antiplaque agents. Antimicrob. Agents Chemother. 12:107-113. 